\title{
SMART PORTABLE CRYOTHERAPY SYSTEM REPHRASED I.E. WITH CONTROLLED THERMOELECTRIC COOLING MODULES FOR MEDICAL APPLICATIONS
}

\author{
Abbas Rahmani ${ }^{1}$, Reza Hassanzadeh PaCk Rezaee ${ }^{2}$ AND \\ NASER KORDANI ${ }^{3 *}$ \\ ${ }^{I}$ Department of Electrical Engineering, Islamic Azad University, \\ Science and Research Branch, Tehran, Iran \\ ${ }^{2}$ Department of Electrical Engineering, University of Guilan, Guilan, Iran \\ ${ }^{3 *}$ Department of Mechanical Engineering, College of Engineering, \\ University of Mazandaran, Babolsar, Iran \\ "Corresponding author: naser.kordani@umz.ac.ir
}

(Received: 27th Dec 2016; Accepted: $17^{\text {th }}$ Oct 2017; Published on-line: $1^{\text {st }}$ June 2018)

https://doi.org/10.31436/iiumej.v19i1.791

\begin{abstract}
When a person suffers from an injury, there are specific methods of treatment which are recommended according to the type of injury. One of these methods involves Cryotherapy, in which the part of the affected body is exposed to cooling for decreasing the temperature. The aim of this therapeutic method is to decrease cellular metabolism, increase cellular survival, decrease inflammation and reduce pain and spasm. The system designed in the present study involves the possibility of "smart" treatment using portable thermoelectric cooling devices based on electronic hardware, software and digital control techniques. In the proposed system, all stages of treatment have been performed automatically by using Arduino as the microcontroller to controlling temperature in cryotherapy methods. This research focus on usage of thermoelectric effect with Peltier module for smart electronic cooling and does not involve the usage of chemicals or cooling materials e.g. ice. Smart cooling methods have significant advantages that they are highly accurate and allow precise timing of the treatment especially for the athletes, and for whom the recovery time from injuries is critical. This approach can be fundamentally important for practical investigations relating to the timing of cryotherapy for any type of users.
\end{abstract}

ABSTRAK: Apabila seseorang mengalami kecederaan, terdapat kaedah rawatan khas yang disyorkan berdasarkan jenis kecederaan. Salah satu kaedah ini melibatkan Krioterapi, di mana sebahagian kawasan badan yang terlibat didedahkan kepada kesejukan untuk megurangkan suhu badan. Tujuan kaedah terapeutik ini adalah bagi mengurangkan metabolisme sel, menambah sel selamat, mengurangkan radang dan mengurangkan sakit dan sentakan. Sistem yang direka dalam kajian ini berkemungkinan melibatkan rawatan bijak yang menggunakan alat penyejuk termoelektrik mudah alih melibatkan peranti elektronik, perisian dan teknik kawalan digital. Dalam sistem cadangan ini, kesemua peringkat rawatan telah dilaksanakan secara automatik menggunakan Arduino sebagai alat mikro-kawalan bagi mengawal suhu dalam kaedah Krioterapi. Fokus kajian ini adalah dengan menggunakan kesan termo-elektrik dengan modul Peltier untuk penyejuk elektronik bijak dan tidak melibatkan penggunaan bahan kimia dan bahan penyejuk seperti ais. Kaedah penyejuk bijak ini mempunyai faedah ketara seperti sangat tepat dan memberi masa rawatan yang jitu terutama untuk atlet, dan 
kepada sesiapa yang tempoh masa pemulihan kecederaan amat penting untuknya. Pendekatan ini boleh menjadi asas penting bagi penyelidikan praktikal berkaitan masa krioterapi untuk pelbagai jenis pengguna.

KEYWORDS: cryotherapy; thermoelectric effect; medical devices; microprocessor controls

\section{INTRODUCTION}

Given the type of damage that occurs in tissues, e.g. in a sprain, strain or muscle-pull or tear, suitable primary measures have been suggested for treatment through the PRICE approach which is an acronym for Protection, Rest, Ice, Compression and Elevation. This method begins with the protection of the affected members against further damage and harmful movements and actions. This involves, for example, the use of bandages, splints and immobilisation by means of special coatings which can protect the injured member against damage or deterioration. Resting is the next step and, at this time, the affected member must be prevented from moving and this stage is important to prevent increasing the level of inflammation. In the next part of the therapy, the member must be cooled, since cooling the damaged member reduces inflammation. Cooling should, ideally, be started from the first minute of injury and, depending on the extent and severity of injury, the cooling period should last between 48 and 72 hours [1]. This usually involves putting an ice pack on the affected area. The next step is to apply pressure to the injury which prevents further inflammation in the damaged tissue. This lowers the level of inflammation of the member and is effective in producing a more rapid improvement. Pressure on the vulnerable area by means of a bandage or the use of elastic bands may also be helpful. In the final treatment, the damaged member is supported to reduce the pressure on it $[2,3]$. In this paper, novel structures and algorithms have been proposed for developing optimal Cryotherapy effective time for different users based on the most wellknown therapeutic methods. We suggest the use of a "smart" Cryotherapy device to replace the use of ice within the PRICE system. This involves placing an electronic device on the ordinary ice packs. With cooling liquid within it, the system is based on new programmable cryotherapy methods which are suitable for all kinds of users (human \& animal).

\subsection{Cryotherapy}

There are various common methods for cooling injured members within the PRICE system in connection with rehabilitation therapy to reduce inflammation and pain relief. Cooling has been accepted as a treatment of choice for acute soft tissue injury $[4,5]$. In this case, part of the patient's body or his/her whole body is exposed to reduce temperatures and therefore the cooling effects reduces the physiological changes that lead to negative effects in both muscle and other tissues [6-11]. This kind of Cryotherapy can be performed using a number of different methods, namely, immersion in cold water, ice massage and use of a gel ice pack, an instant ice pack and a spray or a cooling device [1216]. In the proposed approach mentioned in this paper a smart treatment based on thermoelectric cooling (TEC) device has been used for ice pack temperature adjustment. In this system, the temperature of TEC device being controlled by means of a processor and a temperature sensor which is connected to a microcontroller.

\subsection{Thermoelectric Cooling (TEC) Device}

In a TEC system, the electronic element is located so that the parts that must be cooled are positioned up against the cold side, with a heat sink positioned appropriately 
as shown in Fig. $1[17,18]$. When a DC voltage is applied to a thermoelectric system of the type shown in Fig. 1, thermal energy is transferred from the one layer (the cold end) and this is released at the other side (the hot end). Thus the cold part of the electronic element becomes colder and heat naturally flows from the system. The hot side and cold side temperature formulae for the thermoelectric device are:

$$
\begin{aligned}
& \mathrm{T}_{\mathrm{h}}=\mathrm{T}_{\mathrm{amb}}+\mathrm{O} \cdot \mathrm{Q}_{\mathrm{h}} \\
& \mathrm{Q}_{\mathrm{h}}=\mathrm{Q}_{\mathrm{C}}+\mathrm{P}_{\mathrm{in}}
\end{aligned}
$$

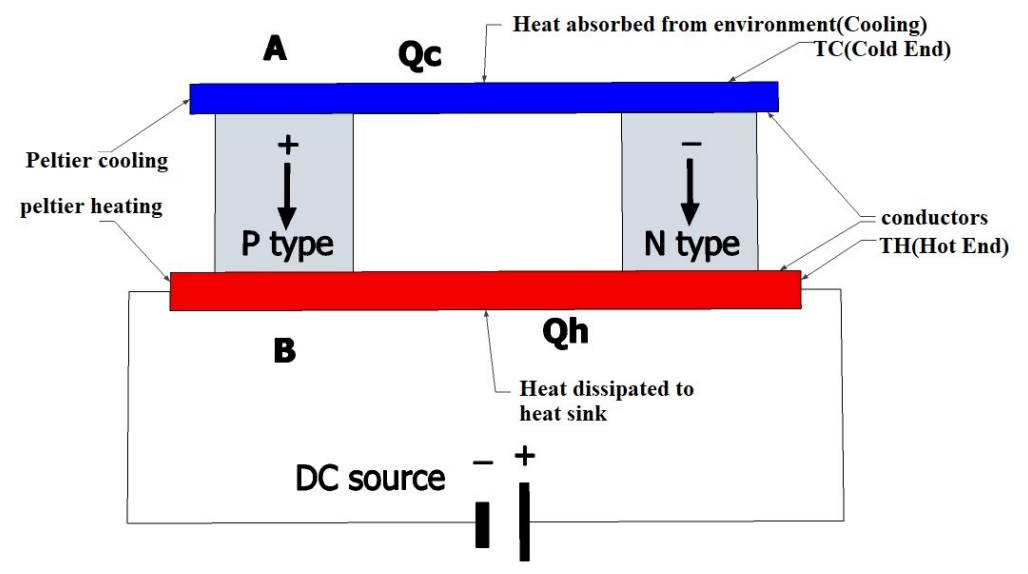

Fig. 1: Schematic of thermoelectric cooler.

In these equations $T_{h}$ is the temperature of the hot side and $T_{a m b}$ is the second temperature level, the parameter $\mathrm{O}$ is the system thermal resistance $\left({ }^{\circ} \mathrm{C} / \mathrm{watt}\right)$. The quantity $\mathrm{Q}_{\mathrm{h}}$ is the heat released (watts) and $\mathrm{Q}_{\mathrm{C}}$ is the heat that is absorbed (watts). The quantity $\mathrm{P}_{\mathrm{in}}$ is the thermoelectric power input (watts). The parameters $\sigma_{\mathrm{p}}, \sigma_{\mathrm{n}}, \lambda_{\mathrm{p}}$, and $\lambda_{\mathrm{n}}$ represent the electrical and thermal conductivities of the $\mathrm{p}$ and $\mathrm{n}$ legs and involve a block of length $L$. The index i refers to either $p$ or $n$, the thermal conductance $K$ is given by [19]:

$$
\mathrm{K}_{\mathrm{i}}=\lambda_{\mathrm{i}} . \mathrm{A}_{\mathrm{i}} / \mathrm{L}_{\mathrm{i}}
$$

The total thermal conductance $\mathrm{K}$ for $\mathrm{N}$ elements is given by [19]:

$$
\mathrm{K}=\mathrm{K}_{\mathrm{p}} \cdot \mathrm{K}_{\mathrm{n}}=\mathrm{N}\left[\lambda \mathrm{p} \mathrm{A} / \mathrm{L}_{\mathrm{p}}+\lambda_{\mathrm{n}} \cdot \mathrm{A}_{\mathrm{n}} / \mathrm{L}_{\mathrm{n}}\right]
$$

The quantities $\mathrm{K}_{\mathrm{p}}$ and $\mathrm{K}_{\mathrm{n}}$ are the thermal conductance of the two side of the TEC. We need also to determine the electrical resistance as calculated by [20]:

$$
\mathrm{R}=\mathrm{R}_{\mathrm{P}}+\mathrm{R}_{\mathrm{n}}=\mathrm{N}\left(\left(\sigma_{\mathrm{p}} \cdot \mathrm{A}_{\mathrm{p}} / \mathrm{L}_{\mathrm{p}}\right)^{-1}+\left(\sigma_{\mathrm{n}} \cdot \mathrm{A}_{\mathrm{n}} / \mathrm{L}_{\mathrm{n}}\right)\right.
$$

Here $R_{P}$ and $R_{N}$ are the electrical resistances of the two side of the TEC. For calculating $\mathrm{Q}_{\mathrm{h}}$ and $\mathrm{Q}_{\mathrm{C}}$, we need to know the coefficient for the two junctions calculated from:

$$
\overline{\mathrm{a}}=\left(\frac{1}{\mathrm{TC}-\mathrm{TH}}\right) \int_{\mathrm{TC}}^{\mathrm{TH}}(\alpha \mathrm{P}-\alpha \mathrm{N}) \mathrm{dt}
$$

The quantity $\overline{\mathrm{a}}$ is the coefficient for the two junctions. Then the magnitudes of the heat input and output are [21]: 


$$
\begin{aligned}
& \mathrm{Q}_{\mathrm{H}}=\mathrm{H} \cdot \overline{\mathrm{a}} \cdot \mathrm{T}_{\mathrm{H}} \cdot \mathrm{I}+\mathrm{K} \cdot \Delta \mathrm{T}-1 / 2 \cdot \mathrm{I}^{2} \mathrm{R} \\
& \mathrm{Q}_{\mathrm{C}}=\mathrm{H} \cdot \overline{\mathrm{a}} \cdot \mathrm{T}_{\mathrm{C}} \cdot \mathrm{I}+\mathrm{K} \cdot \Delta \mathrm{T}-1 / 2 \cdot \mathrm{I}^{2} \mathrm{R}
\end{aligned}
$$

Hence we can now see a direct relationship between $\mathrm{K}$ and the temperature coefficient $(\overline{\mathrm{a}})$ and resistance $(\mathrm{R})$ and the current flow. To reduce the temperature, it is necessary to reduce the temperature by an amount $(\Delta \mathrm{T})$ at the hot side of the thermoelectric module and we can use the heat sink and fan for this purpose. To enhance the process of reducing the temperature of the ice packs and also accelerate the decreasing of temperature without increasing the power consumption, we used a larger heat sink than the system required but it should be noted that in this treatment method the required temperature is $5{ }^{\circ} \mathrm{C}$. We do not need to make use of the full capabilities of the thermoelectric module. The use of feedback control of the temperature of inside of the ice pack ensures that the desired temperature can be maintained throughout the treatment period. Compared with other technologies thermoelectric cooling has a number of advantages. For example, the cooling equipment involves no moving parts and so requires less care and maintenance and has an extended lifetime which may be as much as one hundred thousand hours of stable working.

Unlike cooling systems containing chlorofluorocarbon materials that need to be constantly filled up, thermoelectric systems require relatively little routine attention. Temperature control of the component parts of a system of this kind is recognized as being generally good and an approach of this kind can provides a cooling environment which is of the right size and sensitivity for medical applications [22]. Based on the problems mentioned above, in this paper, the aim is to provide smart and programmable methods of water-cooling based on the use of a thermoelectric system that is suitable for a wide range of medical applications.

\section{MATERIALS AND METHODS}

\subsection{Hardware Design and Manufacture of the System}

According to Fig. 2 the hardware components for installation on the ice pack include a TEC with four centimeters width and four centimeters length, 12 volt effective voltage, 15.2 volt maximum permissible voltage, 6 amperage maximum consumption current and 70 centigrade of maximum temperature difference of both sides that involving a cold plate, a heat exchanger, a fan for the cooling part of system and an electronic board. The electronic sub-system consists of an internal part and an external part. The internal part receives feedback from temperature sensors inside the ice pack and transmits the ice pack temperature to an Atmega32 processor for controlling the cryotherapy mechanism. The external part of the electronic board involves a microprocessor sub-system that controls the process of cryotherapy and also sends data through the COM port for "smart" process control operations. Parts of the system in direct contact with the ice pack and must be completely waterproof. We used plastic meld for this part which allowed easy insertion of the main components of the cold side of the system, such as Peltier device, the fan and the LM35 temperature sensor [23]. The heat sink and fan within the heating side of the system are located on the exterior of the device whereas. The LM35 temperature sensors are located on the inside of the device and are isolated from the water using varnish. According to Fig. 2 the hardware components for installation on the ice pack include a TEC with four centimeters width and four centimeters length, 12 volt effective voltage, 15.2 volt maximum permissible voltage, 6 amperage maximum consumption current and 
$70{ }^{\circ} \mathrm{C}$ of maximum temperature difference of both sides that involving a cold plate, a heat exchanger, a fan for the cooling part of system and an electronic board. The electronic sub-system consists of an internal part and an external part. The internal part receives feedback from temperature sensors inside the ice pack and transmits the ice pack temperature to an Atmega32 processor for controlling the cryotherapy mechanism. The external part of the electronic board involves a microprocessor sub-system that controls the process of cryotherapy and also sends data through the COM port for "smart" process control operations. Parts of the system in direct contact with the ice pack and must be completely waterproof. We used plastic meld for this part which allowed easy insertion of the main components of the cold side of the system, such as Peltier device, the fan and the LM35 temperature sensor [23]. The heat sink and fan within the heating side of the system are located on the exterior of the device whereas. The LM35 temperature sensors are located on the inside of the device and are isolated from the water using varnish.

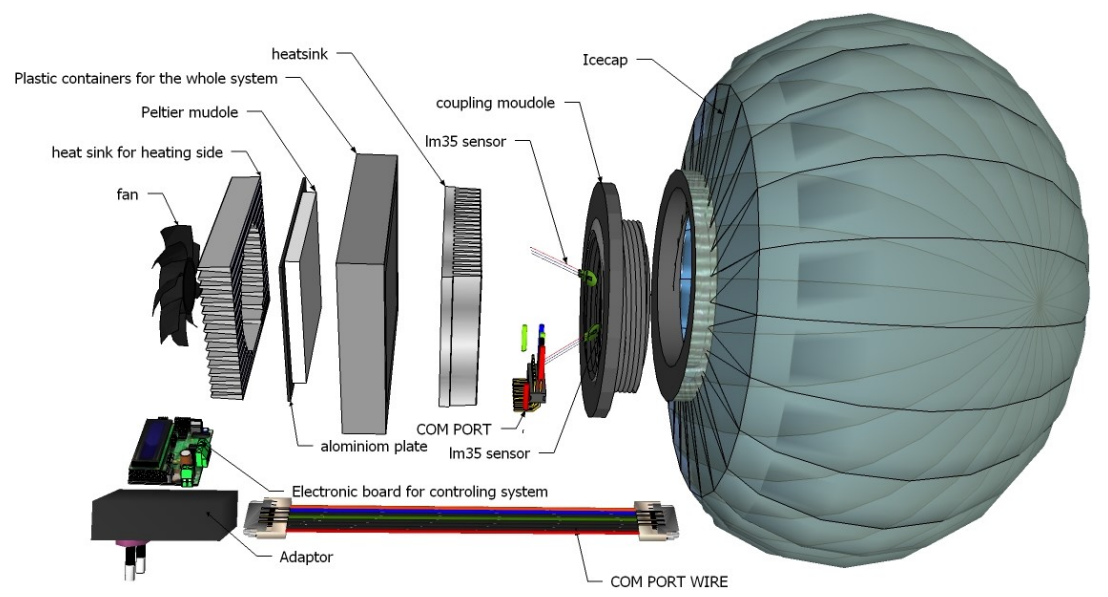

Fig. 2: Computer-based 3-D visualization of the component parts of the system [20].

One of the biggest advantages of this approach to design and manufacture is that the system can be coupled, with no change in its structure, to a conventional ice pack. Different parts of the circuit diagram are shown in Fig. 3 and each section of this is discussed separately.

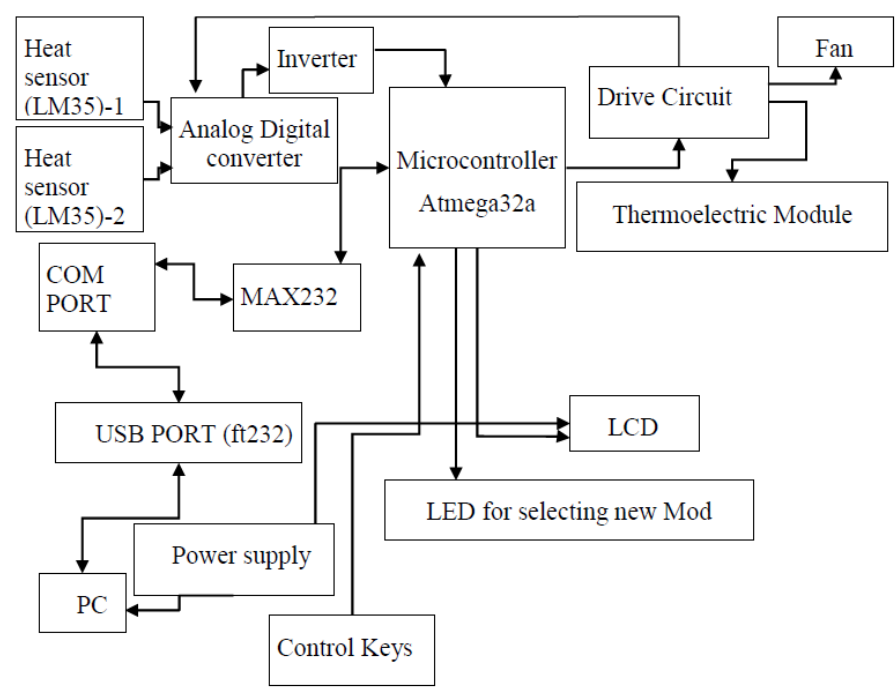

Fig. 3: Schematic diagram of the electronic board. 
The temperature sensor (LM35), analog to digital converter and inverter provide analog temperature information for feedback of temperature in the ice pack to the controller. The MAX232, COM PORT and USB PORT (ft232) send all data to an external PC or some other external programmed system for any special application. The drive circuit provides the required electrical supplies for the Peltier device and all fans within the system. LCD and LED displays are used to provide system status information to the user. Figure 4 shows the complete assembled system.

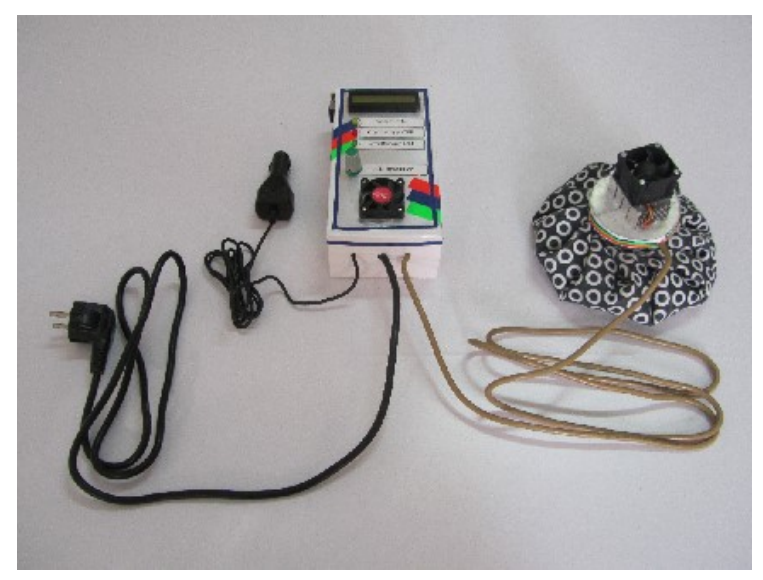

Fig. 4: Assembled systems for use in cryotherapy applications.

\subsection{Performance of the system}

The biggest advantage of the system is its programmable capability for a variety of different applications. The system operation, according to the microprocessor flowchart in Fig. 6 are as follows:

1. System On or Reset;

2. Sensing of the ice pack temperature;

3. System control for the cryotherapy;

4. Feedback of the system temperature for comparison with the desired equilibrium temperature ;

5. Controlled cryotherapy by means of the microprocessor program to perform the required operation for a specific period and then stop after that specified period (e.g. in 48 hours);

6. System Off.

The procedures for the cryotherapy operation outlined above are not the only aspects of system performance that may have to be specified. However the approach based on microprocessor control allows flexibility and permits the designer to incorporate a programmable system which can be tailored according to user's requirements. Appropriate algorithms can be selected by the user. This allows specialist applications such as those for rehabilitation following sports injuries or applications involving animals, such as horses, to be undertaken using the same hardware. In terms of its basic operations, the Atmega32a [24] processor receives feedback from the temperature sensors (LM35) inside the cryotherapy system and compares it with the desired temperature for the cryotherapy process. But it must be notified that practical algorithm structures are different from the investigative ones and there is no need to measure the body temperature from the skin, but in investigative sample it can be done by two sensors. This system is not limited to one particular algorithm and is based on the microprocessor and allows the user to select suitable algorithms for each application and also allows use of the output of the serial port 
to receive and process data from sensors. It should be noted that the hardware system, firstly, should have a very small size and, secondly, it must be understood that it does not fundamentally change the system based on ice packs. The temperature sensor and the vibrator are introduced into the bag structure to move the water and get feedback of temperature values for use in the temperature control algorithm. In Fig. 4, the final assembled structure is shown, including the ice packs, the DC electrical power supply, control system, temperature sensors and Peltier module also are parts of this final assembly. The system provides direct connection to a personal computer via a serial port which allows data to be saved which relates to the performance of the system. This is of potential value for research purposes. In terms of the duration of the therapy, the standard used in previous research involving ice was 15 to 20 minutes of ice every two hours for continuous treatment [25].

Previous studies $[26,27]$ have suggested that the state and duration of cryotherapy should involve an intermittent protocol that reduces skin temperature to $5{ }^{\circ} \mathrm{C}$ immediately after treatment. The process should also involve rest and compression, which reduces swelling and reduces the potential risk of injury [28]. For certain skin conditions and to prevent skin damage, a special program is required for each patient and may involve an algorithm intended for operation over a 48 -hour time period. In general terms, it should be noted that the thermal feedback system stabilizes and the system is turned on at $5{ }^{\circ} \mathrm{C}$ to prevent damage and goes off after 48 hours. This program, as shown in the flowchart of Fig. 6 is a comprehensive program but because it is also a programmable system it allows more accurate planning for any type of patient, avoiding possible harm to humans or animals.

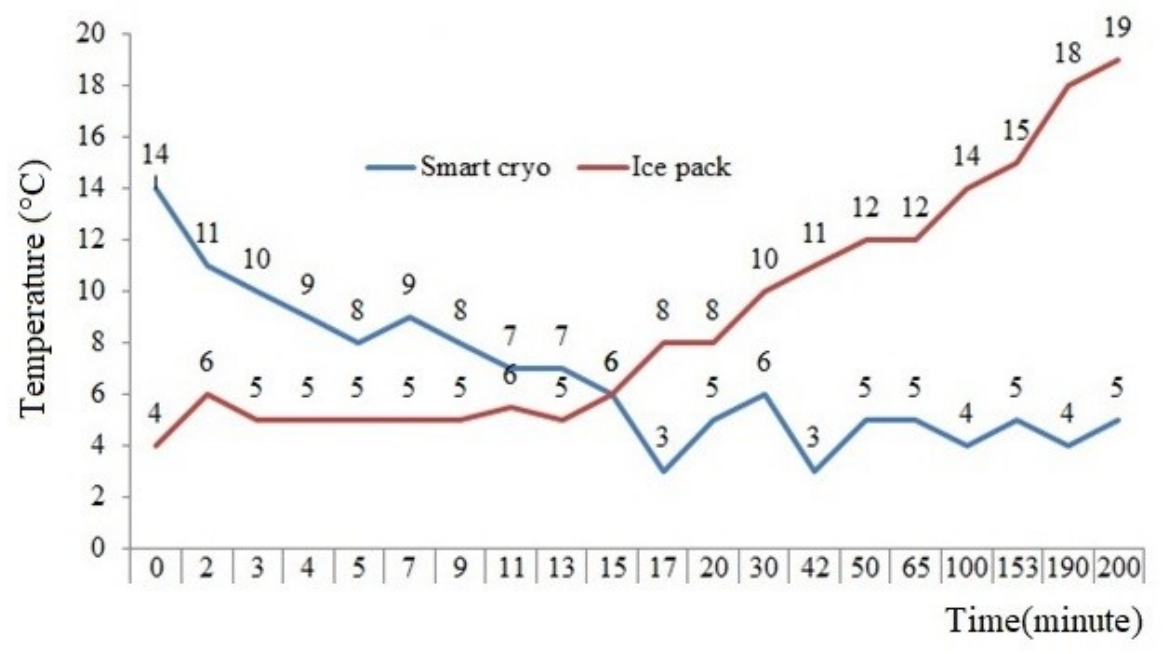

Fig. 5: Ice packs cooling performance charts Smart Cryotherapy System.

Figure 5 shows results comparing the performance of the smart Cryotherapy approach with those obtained using a standard ice pack with 1024 gram weight and in 20 centigrade for the sample with ice and water over a period of 200 minutes. It is evident from these results that it takes some time for the TEC system to reach the desired temperature but then the system continues to operate without any difficulty and the desired temperature is maintained. On the other hand, the temperature of the system involving only the ice pack tends to rise significantly towards the end of the 200 minutes period. It should be noted that the thermoelectric cooling treatment involves a portable piece of hardware that does not require any large structural change in the icepack. The system sends data to a computer for processing. The electronic system involves microprocessor-control and is 
based upon use of the Atmega32a [24] processor to control the system and also provides additional the programming possibilities. The treatment process can be performed automatically using cooling and the system performance can also be observed and evaluated during treatment. With the use of the electronic cooling method instead of a simple physical cooling system using ice packs, it is easier to treat elderly patients, children and animals because the system responds to disturbances and maintains the required temperature automatically with reduced sensitivity to uncertainties and patient-topatient variations. It takes some time for the TEC system to reach the desired temperature but then the system continues to operate without any difficulty and the desired temperature is maintained. On the other hand, the temperature with the ice pack tends to rise significantly towards the end of the 200 minutes period.

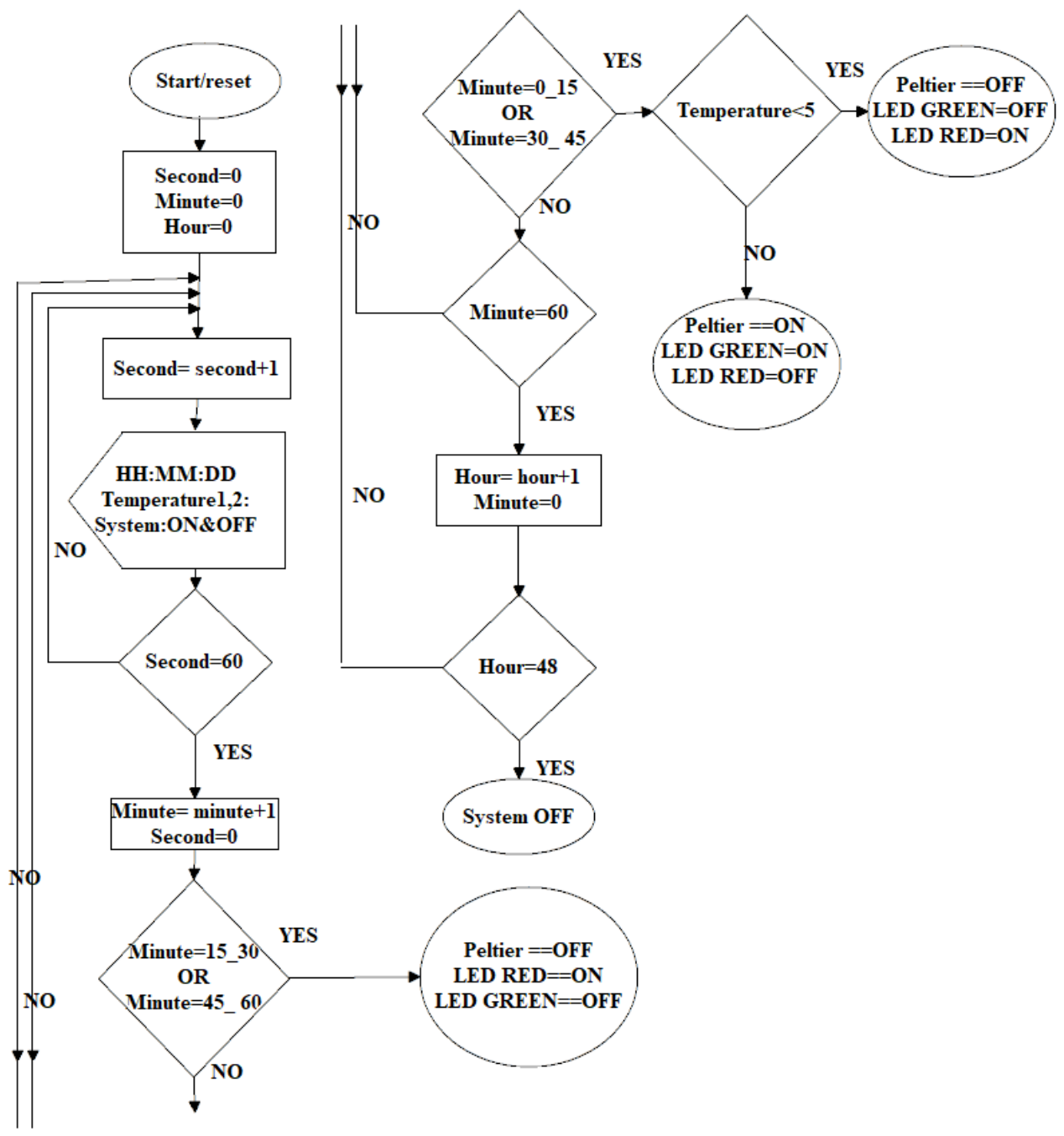

Fig. 6: Flow chart showing microprocessor algorithms during cryotherapy.

Figure 6 shows the flow chart for the microprocessor-based control and indicates how requirements can be changed according to the type of user. For example in the specific flowchart shown in Fig. 6, the system was controlled so that it worked in an on-off mode and with a period of 15 minutes.

\subsection{Software Design for Controlling the Process}


The main aim of system is about vigilant the Cryotherapy process and make the system adjustable to use for finding the effective time of protocol for different medical applications. According to the adjustable structure of macro controller, using a suitable program will fulfill all targets. Paper sampling of ice bag temperature and controlling the cooling process are the important parts of providing design's target. This part is provided by microcontroller analog part that it's server's code in 2.4.2 and the other part is about a comparison of time schedule which is provided by a micro counter timer, is mentioned in 2.4.2 effective voltage of the whole controllable system which is contain of micro controller and some 5 voltage sensors and the sample frequency are provided by the 32.67 $\mathrm{k}$ external crystal, that change the system to a clock so it can control the cooling process all the time and does a current comparison among differences of temperature and time of cooling process. For controlling the microcontroller, we use code vision Avr software for programming the processor and controlling the cryotherapy process. The software consists of several parts:

\subsubsection{Code for Measuring the Value of the Temperature from Inside the Ice Pack}

ADMUX=adc_input $\mid$ (ADC_VREF_TYPE \& 0xff);

delay us(10); ADCSRA $\mid=0 \times 40$; while $((\operatorname{ADCSRA} \& 0 \times 10)=0)$;

ADCSRA $\mid=0 \times 10 ; \mathrm{t}=((\mathrm{ADCW} * 2.56) / 1023) * 100$; while $(1)\left\{\mathrm{t} 0=\mathrm{read} \_\operatorname{adc}(0)\right\}$;

\subsubsection{Code for Introducing the Time for the Course of Treatment}

Interrupt [TIM2_OVF] void timer2_ovf_isr (void)

$\{$ if $($ second $==59$ )

$\{$ second $=0$;

if $($ minute $==59)$ \{minute $=0$;

if $($ hour $==24)$ hour $=0$; else

hour++;\} else

minute++; else

second $++;\}$

\subsubsection{Start of Cryotherapy Involving Algorithm in While Loop}

Control of the Cryotherapy process is in accordance with the following:

if $(5<=\mathrm{T})$

\{PORTD.7=1; PORTD.5=1; PORTD. $6=0 ;\}$

if $(\mathrm{T}<5)$

$\{$ PORTD. $7=0$; PORTD. $6=1$; PORTD. $5=0 ;\}$

Even though all controlled items, for the best temperature transferring in the ice bag a vibrator is used to help the pack to achieve the exact temperature sooner. Besides two sensors are used in the systems, so in investigator samples one of them is used for skin feedback temperature and the other one is used inside the ice bag. In reality the average of sensors temperature can be used for controlling the process in micro. This is sample program for a normal working system. This allows the users to make different patterns for different subjects. This is one of the biggest advantages that can reduce the duration of treatment for special categories of subjects such as professional athletes and the elderly or for animals such as race horses.

\subsubsection{Displaying Information about the Treatment and Time of Cryotherapy}


sprintf(lcd_buff,"Time=\%d:\%d:\%dlnT:\%i'c",hour, minute, second,T);

lcd_clear();

lcd_puts(lcd_buff);

delay_ms(100);

This code just shows all result of timing in display. On/off control is just for controlling cooling system.

\subsubsection{End of Treatment and Shut-down of System}

In this section cryotherapy is ended and the device is switched off. The program shown above is a sample program for operation of the cryotherapy system and provides an illustration of how the time of cryotherapy could be established for any other type of subject. As shown in Fig. 7 the smart cryotherapy system is suitable for use as part of an emergency first aid kit. The system is portable and can be powered from the electrical systems in a car or from a mains electrical supply.

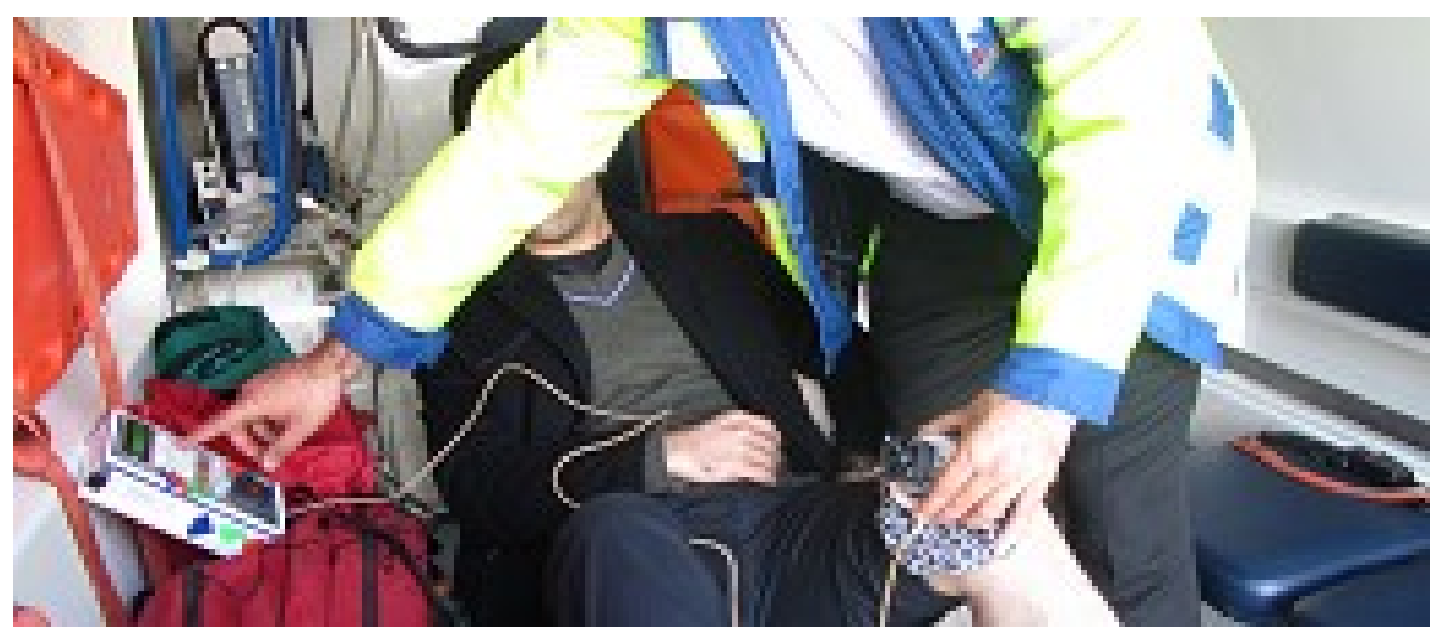

Fig. 7: Smart cryotherapy system in physiotherapy centers and emergency ambulance service.

\section{CONCLUSIONS}

This paper outlines the design of a "smart" system for cryotherapy as Fig. 7 instead of using the systems based on simple ice packs or chemicals that are currently available. It also provides a platform for investigating new procedures for cryotherapy.

The designed prototype has smaller size and lighter weight compared to existing products and traditional designs. The system gets feedback of the temperature of the icepack water and the environment and this allows it to reach the required temperature of 5 $\circ \mathrm{C}$ through the use of suitable and flexible algorithms. The objective of the system outlined in this paper is to make it possible to perform Cryotherapy treatment using a portable charging the system by battery or charging it with automobile charger and programmable system which can be used for a wide range of human patients and for animals. Results presented in the paper show that this has been achieved. This paper has been suggested new device that can find new temperature and time for different type of users and also work fundamentally. 


\section{ACKNOWLEDGEMENT}

The writing of this paper would not have been possible without the support of one person and I wish to take this opportunity to express my profound gratitude and deep regards to Professor David J. Murray-Smith, Honorary Senior Research Fellow, School of Engineering, University of Glasgow, Scotland, U.K. for his guidance, mentoring and constant encouragement during the writing of this paper. The blessing, help and guidance given by him from time to time shall carry me a long way in the journey of life on which I am about to embark.

\section{REFERENCES}

[1] Angelina F, Amilton V, Gracielle VR, Rita de CM, Tania de FS, Gustavo OP \& Joao LQD. (2016) Multiple cryotherapy applications attenuate oxidative stress following skeletal muscle injury. Redox Report, pp 1-7.

[2] Elizabeth Q. (2011) First Aid for Soft Tissue Injuries - Start with the PRICE Protocol PRICE first aid guidelines - Protection, Rest, Ice, Compression and Elevation. Medical Review Board.

[3] Chris MB, Seán O, Mark AT, Laurence GR, Domnhall CM and Suzanne M. (2011) Design of a randomised controlled trial comparing standard versus cryokinetic ice applications in the management of acute ankle sprain. ISRCTN, 39-46.

[4] Bleakley CM, McDonough SM, MacAuley DC. (2006) Cryotherapy for acute ankle sprains: a randomized controlled study of two different icing protocols. Br J Sports Med., 640:700705 .

[5] Huang A, McCall JM, Weston MD, Mathur P, Quinn H,Henderson DC, Allen-Mersh TG. (2002) Phase I study of percutaneous cryotherapy for colorectal liver metastasis. Br J Surg 89(3):303-310.

[6] Hardy M, Woodall W, J Hand T. (1998) Therapeutic effects of heat, cold, and stretch on connective tissue. 11:148-156.

[7] Knight KL. , IL (1995) Human Kinetics, Champaign Cryotherapy in Sport Injury Management.

[8] Kellett J. (1986) Acute soft tissue injuries: a review of the literature. Med Sci Sports Exerc., 18:489-500.

[9] Myrer JW, Measom G, Fellingham GW. J Athl T. (1998) Temperature changes in the human leg during and after two methods of Cryotherapy. 33:25-29.

[10] Swenson C, Sward L, Karlsson J. Scand J. (1996) Cryotherapy in sports medicine. Med Sci Sports, 6:193-200.

[11] Enwemeka CS, Allen C, Avila P, Bina J, Konrad J, Munns S. (2002) Clinical Sciences: Clinically Relevant. Soft tissue thermodynamics before, during, and after cold pack therapy. Medicine \& Science in Sports \& Exercise, 34(1):45-50.

[12] Hanley J, McKernan A, Creagh MD, Classey S, McLaughlin P, Goddard N, Briggs PJ, Frostick S, Giangrande P, Wilde J, Thachil J, Chowdary P. (2017) Musculoskeletal Working Party of the UKHCDO Guidelines for the management of acute joint bleeds and chronic synovitis in haemophilia. Haemophilia. Doi:10.1111/hae.13201.

[13] Chris MB, Seán O, Mark AT, Laurence GR, Domnhall CM and Suzanne M. (2007) Design of a randomised controlled trial comparing standard versus cryokinetic ice applications in the management of acute ankle sprain. ISRCTN, 1390: 39-46.

[14] Browne GJ, and Barnett, P. LJ. (2016) Common sports-related musculoskeletal injuries presenting to the emergency department. Journal of Paediatrics and Child Health, 52:231236. doi:10.1111/jpc.13101.

[15] Hotfiel T, Carl H. D, Grim C, Engelhardt M. (2016) Management of Injured Athletes at the Field, Foot and Ankle Sports Orthopedics. DOI 10.1007/978-3-319-15735-1_8. 
[16] Brison RJ, Day AG., Pelland L, Pickett W, Johnson AP, Aiken A et al. (2016) Effect of early supervised physiotherapy on recovery from acute ankle sprain: randomised controlled trial. BMJ. 355-i5650.

[17] Ni, Liang H. (2007) Zhejiang University (People's Republic of China): Synthesization and properties of Bi2Te3 based nanocomposite thermoelectric materials, ProQuest LLC. H445368.

[18] Michael JN. (2016) The Effectiveness of Water Vapor Sealing Agents When Used in Application with Thermoelectric Cooling Modules, TE Technology, Inc., 1590 Keane Drive, Traverse City, MI 49686.

[19] Gao M, Rowe DM. (1992) Optimisation of thermoelectric module geometry for waste heat electric power generation. Journal of Power Sources, 38:253-259.

[20] Abbas R, (2012) Smart Cryotherapy Active System by Controlling Thermoelectric Cooling Modules. Iran invention reg office: 77326, date of invention.

[21] Decher R, (1997) Direct Energy Conversion - Fundamentals of electric power production" Oxford University press, Inc., 198 Madison Avenue, New York. ISBN 0-19-509572-3.

[22] Dolan MG. Thornton RM, Fish DR. Mendel FC. (1997) Effects of cold water immersion on edema formation acler blunt injury lo the hind limbs of rats. J Arht Train., 32(3):233-237.

[23] http://www.ti.com/product/LM35.

[24] http://www.atmel.com/products/microcontrollers.

[25] Kerr KM, Daily L, Booth L. (1982) Guidelines for the management of soft tissue (musculoskeletal) injury with protection, rest, ice, compression and elevation (PRICE) during the first 64 hours. London: Chartered Society of Physiotherapy, McMaster WC. Cryotherapy. Physician Sportsmed. 10(11):112-119.

[26] Knight KL, Brucker J, Stoneman PD, Rubley MD. (2000) Muscle injury management with Cryotherapy. Athl Ther Today. 5(4):26-30.

[27] Carol F. (2012) The use of ice in patient management - A brief review the evidence.

[28] Haynes DH, Monaghan WP. (1984) Blood storage and transport in the field using a portable thermoelectric refrigerator: assessment of potential use. Military Medicine. 149(4):184-188. 